\title{
Contributions on the regionalization process in two regions in the Southeast of Brazil
}

\author{
Liza Yurie Teruya Uchimura 1 \\ Maria Paula Ferreira 2 \\ Miriam Regina Souza 3 \\ Ana Luiza d'Ávila Viana 4
}

1,3,4 Departamento de Medicina Preventiva. Faculdade de Medicina. Universidade de São Paulo. Av. Dr. Arnaldo, $4552^{\circ}$ andar. São Paulo, SP, Brasil. CEP: $01.246-903$.
E-mail: lytuchimura@gmail.com

2 Fundação Sistema Estadual de Análise de Dados. São Paulo, SP, Brasil.

\begin{abstract}
Objectives: to analyze the contributions of regionalization in North-Barretos and SouthBarretos regions, focusing on political, structural and organizational changes.

Methods: mixed sequential explanatory methods using records analysis from the Comissão Intergestores Regional (CIR) (Regional Inter-managers Commission (CIR), interviews with questionnaire and guides along with 42 key agents (managers and providers of services) conducted in August 2015. The descriptive statistical results were presented with mean scores for each of the question in the questionnaire. The analysis of the thematic content was performed by using the Atlas-ti software and categories of the mixed themes were generated representing the following dimensions: policy, structure and organization.

Results: the study identified that the Estrutura Regional da Secretaria Estadual de Saude (Regional Structure of the State Health Department) is the most important institution in health policy decisions. Several contributions can be identified in the process of regionalization, mainly in the organizational aspect of the health system. The records demonstrated the frequent presence of themes related to networks, regulation and financing and the definition of flow of patients.

Conclusions: regionalization in the North-Barretos and South-Barretos regions have contributed for a better organization in health actions and services. The intergovernmental forums do not work with coordination and they are not a collaborative place to negotiate health issues in these regions in São Paulo State
\end{abstract}

Key words Regionalization, Health system, Health policies 


\section{Introduction}

In recent years, Brazil presented a reduction of social inequalities, taking into account the distribution of the income in the base population. However, the concentration of cities with higher rates of poverty remains in the North and Northeast regions in the country. ${ }^{1}$ Albuquerque et al. ${ }^{2}$ reported that the regional policies in health assisted in advances to minimize these inequalities through the prioritization of regional strategies intergovernmental organizations and the development of health care services. Other authors reinforce that the regionalization process could be much more developed if there was a better appropriation of territory complexities. In other words, an inclusion of economic, social, political, institutional and individual aspects in the articulations of the regional governance. 3

The normative surveys and documentary on the Sistema Único de Saúde (SUS) (Unified Health System) regionalization show that this health policy has been constructed from a techno-political point of view. There is a need for new regulatory arrangements that definitely guarantees SUS development and health management professionalization. ${ }^{4}$

Despite being present in the constitutional text 5 and identified as one of the attributed key for public health, as the right for all Brazilian citizens, the regionalization only became an effective policy in the year 2000s. ${ }^{6}$ From there, it was established that health services should be organized in hierarchical regional networks. 5

Carvalho et al. 4 emphasize the need to build regional policies according to the historical and cultural reality in health management. The regionalization, as an attribute to SUS, has main objectives of: to increase the accessibility and reduce inequalities, strengthen the principles of universality and equity. ${ }^{7}$ In recent years, accompanying the regionalization and the regional income growth, it was made possible to identify improvements in the regional distribution of services in medium and high complexity and of the health professionals. ${ }^{2}$ According to Canadian experience, regionalization, besides these goals, could define the region as a territory, strengthen the regional authorities and improve the health system organization. ${ }^{8}$ Because it is such a dynamic area of cooperation for different agents, the health region represents an area with great potential to build networks with collaborative mobilization efforts. ${ }^{3}$

In this process of implanting health policy, São Paulo State, along with other Federative units in the Country, was responsible for the regionalization coordination between the Federal Government and the city, adapting to each norm approved by the Federal level and modifying its institutions which is already present. 9 The regionalization in São Paulo State anticipated the National movement with the regional instances foundation before the Constitution of $1988.10,11$

In 1986, the Escritórios Regionais de Saúde (ERSA) (Regional Health Offices) were created and distributed in regionalized and decentralized areas in São Paulo State. The ERSAs constituted a new example in each region to integrate its services from the Secretaria Estadual de Saúde de São Paulo (SES-SP) (Secretary of State Health Department in São Paulo) in objective to coordinate and run health programs, as well as evaluate the achieved results. 10

Aligned with the National Health Policy, São Paulo State in 1995 substituted the ERSAs for 24 Diretorias Regionais de Saúde (DIR) (Regional Board Members of Health). In addition, created the Gabinete de Coordenação da Saúde da Região do Interior and the Gabinete de Coordenação da Saúde da Região Metropolitana (Health Coordination Office in the countryside region and in the Metropolitan Region).12 Parallel to the National Deployment Process of the Norma Operacional de Atenção à Saúde (NOAS) (Operational Norm for Healthcare), the State organized 65 micro-regions, which the final design was similar to the old ERSAs design. 10

In 2006, with the introduction of the Pacto de Saúde (Pact Health), the SES-SP started a new administrative reform, transforming 24 DIR in 17 Departamentos Regionais de Saúde (DRS) (Regional Health Departments). Allied to this reform, the Coordenação da Saúde (Health Coordination), de Coordenação de Serviços de Saúde (Health Services Coordination), de Coordenação de Gestão de Contratos (Contract Management Coordination), de Coordenação Tecnológica (Technology Coordination) and even the Gabinete Estratégico de Entradas de Saúde (Health Strategic Inputs Office) and Controle de Doenças ${ }^{13}$ (Disease Control) were created.

In 2010, the Decree Number 4,279 established the guidelines as forms organize the health services, which had been institutionalized through Redes de Atenção à Saúde (RAS) (Healthcare Networks). ${ }^{14}$ The population, the operational framework and the health care models were presented as essential constitutional elements of RAS. 15

The Health Ministry with the approval of the Decree Number 7,508 in 2011, reorganized SUS as a regional and hierarchical form, and by the Termo de 
Referência (Reference Term), São Paulo outlined the concepts, criteria and health services in the flow process, creating Redes Regionais de Atenção à Saúde (RRAS) (Regional Healthcare Networks). These regional networks were characterized as the "formation of the horizontal, systematized and regulated relation organized among primary care and other points of care in the health system." 10

The Decree also established the Comissão Intergestores Regional (CIR) (Regional Intermanagers Commission), strengthening the relations between the State and the cities which, until then, had low autonomy in comparison to other policy spheres. There have been regular meetings with representatives of the Secretaria de Estado da Saúde (State Health Secretary), all the Health Secretaries of the Cities and various others interested (public or private) in what characterized this regional area of governance. 16

As mentioned above, some questions were raised: did the regionalization in the North-Barretos and South-Barretos regions contribute to political, structural or organizational aspects? Did the CIR introduce themselves as collaborative spaces for negotiation among the different spheres of the North-Barretos and South-Barretos? Has the regionalization helped improve the health planning?

Thus, this study aims to analyze the contributions of regionalization in the North-Barretos and South-Barretos regions in São Paulo, Brazil, focusing on political, structural and organizational changes.

\section{Methods}

It is a study of mixed methods to employ quantitative methods with magnitude evaluation and construction of frequencies, and qualitative methods that exploit the meaning and the understanding of constructions. The choice to approach mixed methods is justified by a better understanding of the data. The selection of only one quantitative or qualitative study design is insufficient to analyze and interpretate the hypothesis of the research. 17 This study is the outcome of this research "Politica, Planejamento e Gestão das Regiões e Redes de Atenção à Saúde no Brasil" (Policy, Planning and Management in Regions and Healthcare Networks in Brazil), financed by funds from the Ministério da Ciência, Tecnologia e Inovação (MCTI) (Ministry of Science, Technology and Innovation) and by the Ministério da Saúde (Ministry of Health) by the socalled MCTI/CNPq/CT - Saúde/MS/SCTIE/Decree number $41 / 2013.18$
The Departamento Regional de Saúde-V (DRSV) (Regional Health Department V) in São Paulo State has a coverage area of $8,099 \mathrm{~km}^{2}$, representing $3.3 \%$ of the Paulista territory, divided into two health regions: North-Barretos and South-Barretos. Together, they represent 18 Cities: Altair, Barretos, Bebedouro, Cajobi, Colina, Colômbia, Guaíba, Guaraci, Jaborandi, Monte Azul Paulista, Olímpia, Severínia, Taiaçu, Taiuva, Taquaral, Terra Roxa, Viradouro and Vista Alegre do Alto (Figure 1). These Cities present inferior socioeconomic indicators in São Paulo State, but higher than the National average. In 2015, according to data from the Cadastro Nacional dos Estabelecimentos de Saúde (CNES) (National Registry of Health Establishments) in the North- Barretos region has in total nine hospitals and South- Barretos has five of these services. We emphasized the first region, the presence of the Hospital de Câncer de Barretos (Cancer Hospital in Barretos) administered by the Fundação Pio XII (Pius XII Foundation), a National reference hospital for Oncology patients with exclusive SUS service. In addition to this, this region has an important general hospital, Santa Casa de Barretos. There are 38 registered equipment among the specialized outpatient clinics, the Ambulatórios Médicos Especialidades (AME) (Specialized Medical Ambulatories) Clínico e Cirúrgico da SES$S P$ (Clinic and Surgical), whose responsibility is also by the Fundação Pio XII. In primary healthcare, there are medical records in 54 health units in the North-Barretos region and 40 in the South with a population coverage estimated at $56.7 \%$ by the Estratégia de Saúde da Família (ESF) (Family Health Strategy) in both regions.

The North-Barretos and South-Barretos regions were selected intentionally based on a combination of factors: the classification of the Censo Demográfico 2010 (Population Census), conducted by the Instituto Brasileiro de Geografia e Estatística (IBGE) (Brazilian Institute of Geography and Statistics); the Sistema Único de Saúde (Public Health Syytem) database available in the Datasus and the Sistema de Contas Regionais (IBGE) (Regional Account System). Based on these databases, the variables were selected which represented moderate/high socioeconomic development and moderate/high service offerings; the hierarchy and urban complexity; the presence of cities included in the Projeto Rede QualiSUS (Network QualiSUS Project) and the presence of a Medical College.

As a selection criterion, the health regions typology was also used proposed by Viana et al.,19 who adopted the cluster analysis for the socioeco- 
Figure 1

Regional Health Department V (DRS-V). São Paulo, 2012.

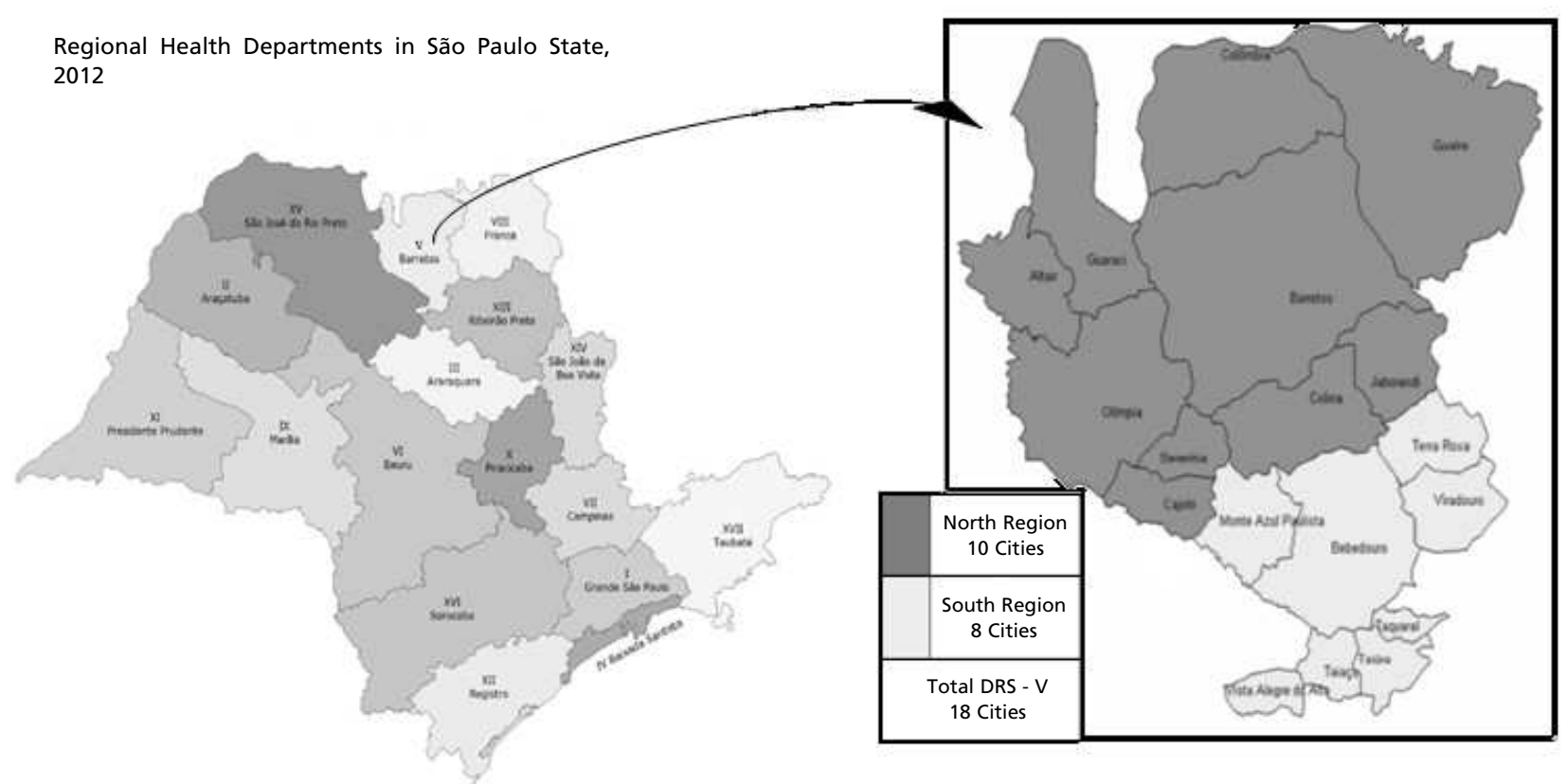

Source: www.saude.sp.gov.br

nomic development, offering and health complexity services in the regional context and as the regionalization structural conditions in Brazil. In this typology, the North-Barretos region fits in group 5 (high socioeconomic development and high service offerings) and the South in group 3 (average socioeconomic development and medium/high range of services). The cities selected were those who reported a greater number of health units in the North-Barretos and South-Barretos (Olímpia and Bebedouro), the main City of the DRS-V (Barretos) and also those with the lowest number of health establishments and a population of at least 3,000 inhabitants (Cajobi and Taíuva).

The data collection was performed with a strategy type sequential explanatory using different sources ${ }^{17}$ as the analysis of the CIR meetings, individual interviews with 42 key informants questionnaire and guides for the interviews in the NorthBarretos and South-Barretos regions in São Paulo, Brazil. The CIR reports of the North and South Barretos from January to August of 2015 were analyzed. Seven CIR reports were each analyzed along with an elaborated document of an only meeting in both regions, totaling 15 documents in all.

The interviewees were identified by representing managers, service providers and community representatives in the context of State, Regional and City government spheres. All of them were selected based on the importance of their position at the time of the data collecting, such as Secretaries of City Health, or administrative coordinators in sectors, such as hospitals, primary healthcare, emergency care network, health surveillance, human resources and the distribution of medication.

The interviewees were contacted in advance by phone and/or e-mail to schedule the appointment. These interviews were collected in August 2015 and scheduled an appointment at each interviewee's place of work. In the scheduled day, everyone was informed about the anonymity of the responses and they agreed with the interviews and authorized the recording.

The questionnaires were composed of structured and conducted questions and filled out by the 
Distribution of number of questions according to the dimensions and types of the interviewees. North-Barretos and South-Barretos regions, São Paulo, 2015.

\begin{tabular}{|c|c|c|c|c|c|c|c|c|c|c|c|}
\hline \multirow[t]{2}{*}{ Dimensions } & \multirow[t]{2}{*}{ Questions } & \multicolumn{10}{|c|}{ Type of interviewees } \\
\hline & & $\begin{array}{c}\text { City } \\
\text { Manager }\end{array}$ & $\begin{array}{l}\text { Regional } \\
\text { Manager }\end{array}$ & $\begin{array}{c}\text { State } \\
\text { Manager }\end{array}$ & $\begin{array}{c}\text { City } \\
\text { Service } \\
\text { Provider }\end{array}$ & $\begin{array}{c}\text { Regional } \\
\text { Service } \\
\text { Provider }\end{array}$ & $\begin{array}{c}\text { State } \\
\text { Service } \\
\text { Provider }\end{array}$ & Society & $\begin{array}{c}\text { RUE/ } \\
\text { SAMU* }\end{array}$ & $\begin{array}{c}\text { Pharmaceu } \\
\text { tical } \\
\text { Assistance }\end{array}$ & $\begin{array}{c}\text { Health } \\
\text { Surveillance }\end{array}$ \\
\hline Politics & 59 & 53 & 53 & 8 & 13 & 17 & 51 & 5 & 7 & 10 & 6 \\
\hline Structure & 74 & 44 & 44 & 0 & 31 & 7 & 44 & 0 & 18 & 0 & 16 \\
\hline Organization & 80 & 53 & 53 & 0 & 29 & 0 & 32 & 0 & 17 & 0 & 21 \\
\hline Total & 236 & 173 & 173 & 8 & 94 & 24 & 127 & 5 & 42 & 10 & 43 \\
\hline
\end{tabular}

*RUE/SAMU = Urgency and Emergency Network /Mobile Urgency Care Service.

researcher. The questions were formulated according to the type of the interviewee; therefore, not all the questions were answered by all the interviewees. The questions were categorized in political, organizational and structural dimensions of the health services (Table 1).

For the State and the Community managers, a guide to the open questions was used. These interviews were transcribed. The researchers read the material repeatedly to make the content analysis, prioritize the questions and establish a relation between them.

The CIR reports reflected on the participation of the 17 representatives of the cities in the region, except for South-Barretos region, which did not participate in any of the meetings. The meetings were generally attended by responsible politicians of the cities, except for the pole city, on behalf of which the representative of the city participated in all the meetings. The CIR reports were read repeatedly to identify the topics of the analysis.

The data were tabulated by using PHP Line Survey - Open Source software. The statistical calculations were performed by using the SPSS Statistics for Windows, Version 22.0 (Armonk, NY: IBM Corp.). The descriptive statistical results were presented as the mean scores for each of the questions, expressed in the Likert scale of five points, where one (1) corresponded to the worst score and five (5) to the best. The average scores equal to or greater than 3 indicate a positive evaluation.

The thematic content analysis was performed by using the Atlas-ti software and the categories of themes were mixed generating and representing the following dimensions: politics, organization and structure.
This study was approved by the Ethics Committee at the Faculdade de Medicina da Universidade de São Paulo, through a Decree number. 045/2016, and according to the standard of the Conselho Nacional de Saúde (National Health Council) Number 466/2012.

\section{Results}

The study population was constituted by 42 people and $69.7 \%$ were females and $30.2 \%$ males. In relation to age $47.8 \%$ were between 40 and 60 years old, $39.1 \%$ were less than 40 years, and the remainder was more than 60 years old. Half of interviewees $(50 \%)$ worked in the institution for 10 years or less, $23.9 \%$ worked more than 20 years, $15.2 \%$ were associated to the institution between 11 and 20 years and $11.9 \%$ worked less than one year. Of the total number of the interviewees, $82 \%$ were graduated in areas of biological sciences, $13 \%$ in human sciences and the rest of the interviewees reported having completed high school or did not specify their schooling level.

The analysis of the CIR reports showed the frequent presence of themes related to networks, regulation and financing, such as the regional epidemiological situation in relation to dengue, the transference of financial resources among cities and the definition of patients flows and the cancer examinations.

\section{The Political Dimension}

According to $64 \%$ of the interviewees, the Regional Structure was the main committee institution organizer in the North-Barretos and South-Barretos 


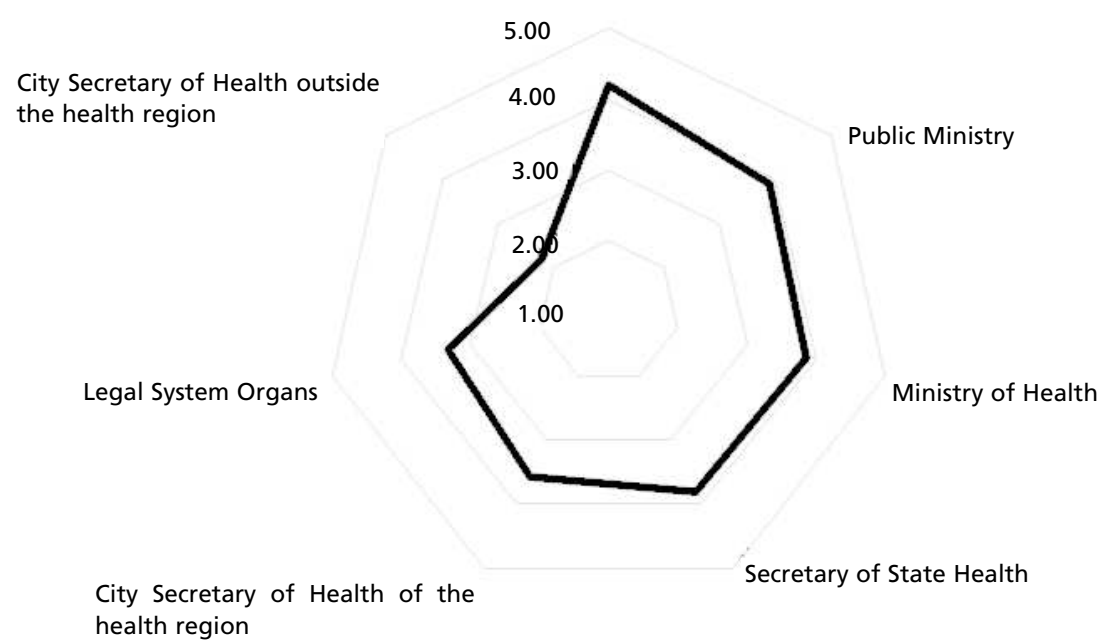

regions, but $32 \%$ of the interviewees from the City Health Department was cited as the most important. The relevance of the public organs in the health system organization for decision-making in NorthBarretos and South-Barretos was classified as follows: Regional Structure (average score - 4.19), the Public Ministry (average score - 3.89), Ministry of Health (average score - 3.86) and the State Health Department (average score - 3.81) (Figure 2).

The public or private health service providers also have influenced on the decisions of health in the regions. According to the interviewees' perception, between health services providers of the institutions in medium and high complexity, they have greater importance in decision-making in the study regions. However, the industries in the health sector have minimal importance on the health decisions in North-Barretos and South-Barretos (Figure 3).

The CIR is predominantly a deliberative space $(83.3 \%)$. The topics on regionalization were discussed in this CIR with the working groups and commissions in the formal meetings. The agendas for the CIR meetings were defined primarily by the Regional Health Structure (83.3\%) and by the City
Secretary of Health $(83.3 \%)$. For the managers of the Health Secretary of State, the CIR worked only with time scheduled for meeting, without being involved in deliberate issues.

Among the interviewees, they did not mention the relevance of the patients, consultants and universities and/or research centers on the definition of the themes to be discussed at the CIR meetings. The main contributions of the CIR for the NorthBarretos and South-Barretos regions were defined as the Healthcare Networks and mediators of conflicts.

According to the interviewees, there are conflicts in relation to the city and region, especially among the pole city and others, on the resources, criteria to access and organizational network. The CIR reports refer to a complementary relationship to the spatial reconfiguration of services and actions directed to expand and ensure access and coverage among the pole city polo and other cities.

The political dimension was the one that required a fewer discussions at the CIR meetings in relation to the aspects of organization and structure. While themes as the planning instruments were rarely discussed, others, such as the vote on the key 
The importance of service providers in decision-making in mean score in North-Barretos and South-Barretos regions, 2015.

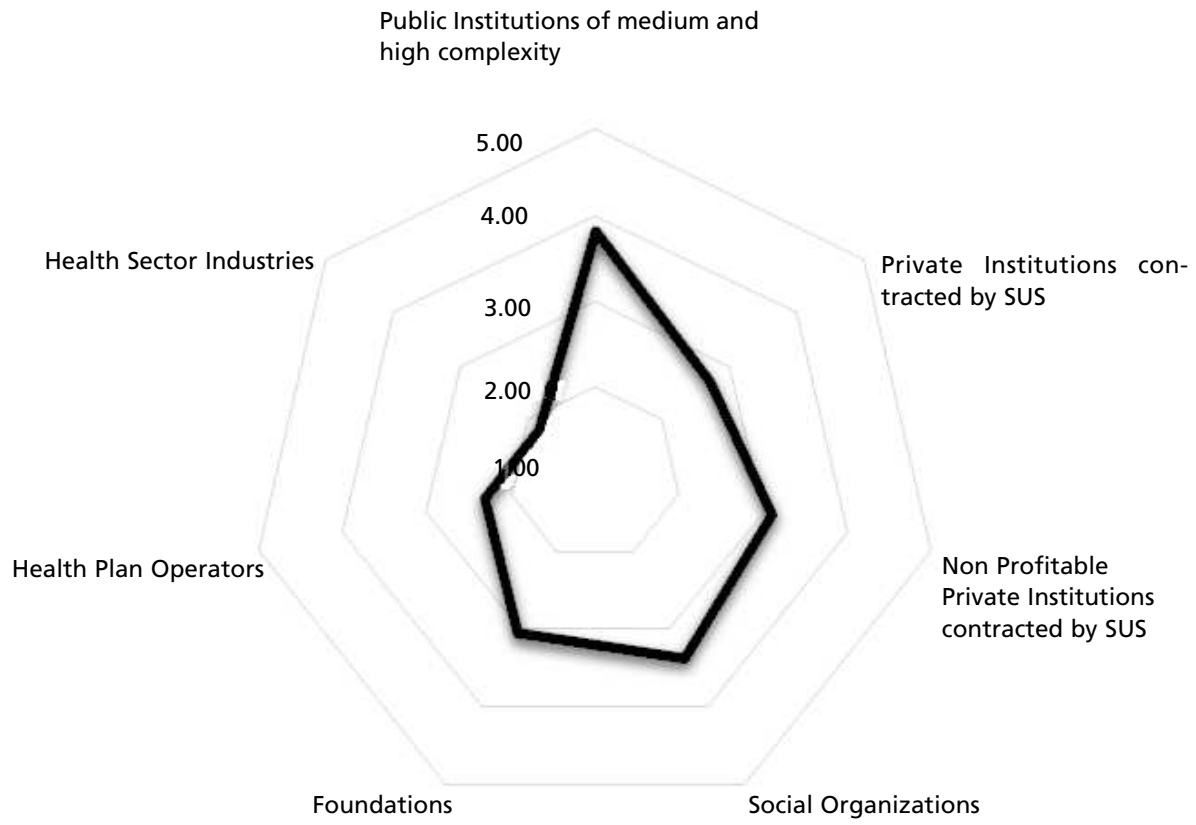

agent for the regional representation were more frequent. The CIR meetings also included the choice of the representatives to discuss technical groups (for example, group conductor on primary care) and the representatives of various segments of society (for example, City health councils). In addition, they established the main responsibility for screening on activities that involve the transference of financial resources.

\section{The Organization Dimension}

Several contributions from the regionalization health process were found mainly in the organizational aspects of the health system. The only meeting between the two sanitary regions was addressed the issue on the health management organization and the approval on the SISPACTO (guideline agreement, goals and indicators), which included agreements on health indices to be achieved by 2015 . The discussions were organized by health attendance networks and by representatives of the NorthBarretos and South-Barretos regions.

The managers of the State Health Department agreed that the regionalization helped build the region through a territorial understanding, the definitions of flows of patients and their health needs. According to the interviewees, the major contributions of regionalization in these regions were on the integration of health services and actions, in the expansion of the access in actions and services at the secondary and tertiary levels of healthcare and regulation assistance. However, the health policy did not modify the panorama of social participation and showed a worsening in the improvement on the financial resources distribution.

The interviewees reported difficulties in the governance of the regions that resulted in a deficient epidemiological indicator and the lowest production. Twenty percent $(20 \%)$ answered about the existence of the Plano de Regionalização em Saúde (Health Regionalization Plan). The difficulties of planning and monitoring were informed by the interviewees. The CIR reports describe the difficulties in planning combat strategies on epidemiological emergencies (such as dengue) and is also mentioned the absence of a local manager in the organization of flows of patients and hospital admissions of patients to referred consultations. Many of these problems are related to the increase lawsuits in health material, which has been difficult to make appointments which are designated for managers to address these legal issues: 
"... A typical case, pediatric cardiac surgery continues to be a problem and has a waiting list, lawsuits are a challenge on this front ..."

For the formation on Healthcare Network are considered several factors: diagnosis on health necessities $(60 \%)$, capacity of regional diagnosis installed in the health services $(60 \%)$, capacity installed in the health services $(60 \%)$ and regional plan for the increase in the offering on primary care (40\%) (Figure 4). Several CIR meetings addressed the installed capacity at the Foundation in pole city and in the organization of regions and considered the RAS formation. However, only $27 \%$ of the health managers believe that there is a sufficient installed capacity for RAS.

The main parameter for the network configuration, according to the interviewees, is the population's territorial distribution (average score4.4). The CIR reports were verified that the populational size in the cities is the main parameter used as a mechanism to distribute quotas among the cities to program elective orthopedic surgeries in a reference hospital in the region. Other parameters were also mentioned as important in building networks (average score - 4.2), such as conditions to have access, transportation or geographical barriers; availability for health services; availability for human resources; financial incentives and the existence of regional council managing. The existing coverage for health plans was considered a criterion of less important for the network (average score 3.0 ) and at any time this discussion was reported in the CIR meetings.

In the reports there are written discussions of referral and counter-referral flows of patients, especially with breast cancer, uterine cervical cancer and patients with melanoma. The mechanisms for referral and counter-referral, the clinical guidelines, the available therapeutic stock and forwarding information were considered integration and coordination mechanisms of RAS.

In regard to the Thematic Networks, all were or are being implemented in the regions with some peculiarities. The Rede de Obstetrícia e Neonatal (Rede Cegonha) (Obstetric and Neonatal Care Network-Stork Network) was much better organized in the North-Barretos and South-Barretos because they already had a previous federal regulations organization. The emergency care was the second most well organized, but none have been totally implemented by managers of Health Secretary of State because it involved many complex services. The Rede Doenças Crônicas (Chronic Diseases Network) was mentioned as the third best. It was organized based on their lines of care for hypertensive, obese, oncology and kidney disease.

In the reading of the CIR reports, it was analyzed

Figure 4

Considered Criteria in the RAS formation in percentage in the North-Barretos and South-Barretos regions, 2015.

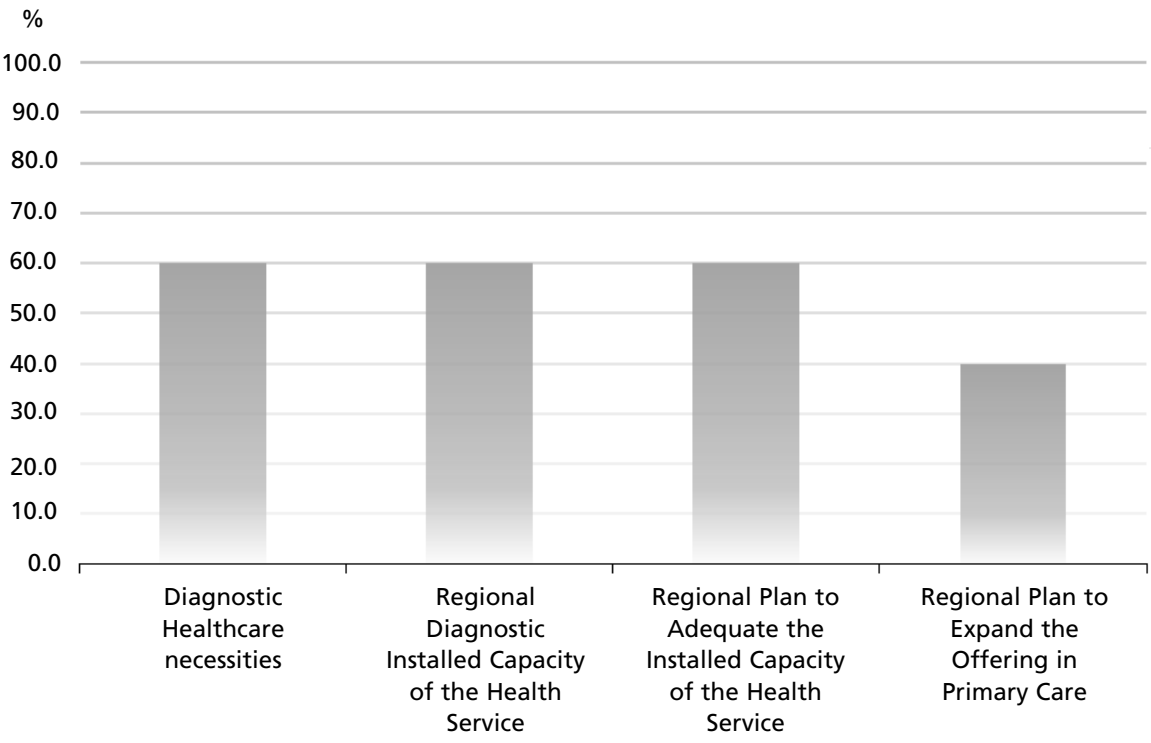


on the most mentioned Thematic Network - the Rede de Atenção à Saúde das Pessoas com Doenças Crônicas (Healthcare Network for People with Chronic Diseases) - and, in particular, the Rede de Oncologia (Oncology Network) due to the influence of the Foundation in the region. The Rede de Emergência (Emergency Network) has been reported in the discussions due to budgetary difficulties or adjustment of clinical cases. The other Thematic Networks were not mentioned during the study period.

\section{Structured Dimension}

For $60 \%$ of the interviewees, the RAS management has ensured timely references to other levels of care in the health system, through the resolution of health problems and the guarantee of the quality of care and patient safety. They believe that this has contributed to the definition of the care flow, the integration of service network in the City and the service integration in the region network, in addition to improving the access to primary care.

The CIR meetings discussed the training of teams in primary care attending at clinical and surgical centers, and also mentioned about pharmaceutical care and the capacity of primary health care. Another problem often discussed was the low offering on health services especially for the Cities in the South-Barretos region. According to a State manager:

"It (the region) is not self-sufficient, it depends on a many other regions, so this is why it is not characterized as a health region"

The combination of structural factors, such as high demand, capacity of insufficient services and human resources, the difficulties got worse facing a network planning on health care. This became evident after an analysis of the repressed demand for services of magnetic resonance imaging and cataract surgeries. To try to overcome these issues, it is necessary to plan better and optimize the capacity by installing health services, São Paulo State counts on the RRAS administration:

"Care for the disabled is managed through the RRAS, chronic diseases, obesity also through the RRAS, oncology as well, and now there are no plans to chronic kidney disease, which is also managed through the RRAS".
The issue on financing was also pointed out as a problem in the regions. The pole city laboratory reported difficulties in the maintenance of the materials and the cities that have sent samples to the laboratory reported problems in transportation contracts. Another issue referred to financing was related to the non up to date of the rates fee procedure at SUS. In other words, the surgery could cost twice the value reported by the company or by the city. The sub-financial occurred in the major referral hospitals in the North-Barretos and SouthBarretos regions discussed in the CIRs. However, for health managers, the investments in the healthcare network over the past three years have increased $66 \%$. The RAS cost was mainly financed by the City Treasury and Federal with little assistance from the State Government.

\section{Discussion}

This study reported the participation of different federative entities in the regionalization process of health in the North-Barretos and South-Barretos regions. As part of the Pacto de Saúde (Health Pact), the solidarity and the cooperative regionalization are placed as a compromise to be guaranteed by the National, City and State Governments to ensure the deployment and provide quality services. 6 According to Carvalho et al.,4 there is a weak institutionalization of the regionalization process whereas the functions of political agents remain imprecise and follows the electrol political cycle.

In this study demonstrated that the leadership of the Regional Structure was represented by the State. For the Pan American Health Organization, 20 the participation of the State Government is essential in conducting regionalization by acting as a mediator in the process. However, there is a fragmentation of the information systems unfeasible in many cases, the State's access to the data of each city, which are sent directly to the National databases. 4

The analysis results showed difficulties in planning the health actions. Also, we confirm what Vargas et al.,21 had already mentioned: that the formation of health networks was based more in negotiations between the interested parties than in the proper planning. Wickremasinghe et al. 22 noticied that for the low income Countries, the data from the information systems on health management were not widely used for decisions making, sometimes because there was a standardized process for their use or because they were poor quality.

In the present study, it was verified that in Brazil these data exist, but in the existing professionals, 
they have no ability in how to work on them for health management purposes - which this was also confirmed in a Pernambuco region in Brazil. ${ }^{21}$ The Plano de Regionalização da Saúde (Health Regionalization Plan) must be an instrumental mechanism, however, to be underutilized for health services and their priorities to make it difficult on the allocation of resources, programmatic and management decentralization. Ribeiro et al., ${ }^{3}$ study suggests that the formal use of the Contrato Organizativo da Ação Pública (COAP) (Public Action Organizational Contract) to monitor purposes and regional planning by following indicators and health goals were agreed among all agents.

In a similar way as Bergevin et al.,23 study, our study confirmed a greater ownership on the necessities in health of the population for the RAS formation, by improving the regionalization process. The authors mention that regionalization has improved the population's health by expanding the intersectoral approaches that facilitate the dialog among the political representatives. ${ }^{23}$ As in the Canadian study, 23 this analysis identified an important contribution of regionalization to integrate the health system, as to improve in the definition of the flow of patients and the regulation of the health services. The Brazilian authors state that the RAS proposal reflects in the recent alignment in the health policy in the Country with International reforms of the universal systems and that the deployment of the RAS has accompanied a different rhythm of the regionalization. ${ }^{2}$

The contribution made by integrating different levels in health care was also confirmed by a study in Denmark, 24 highlighting that the regions and the cities have implemented various initiatives, such as the Pathway programs for chronic diseases, which promotes integrated care. Unfortunately, our study identified that the regionalization did not result a fully regionalized primary care. This is the greatest merit of regionalization in New Zealand, which got this health system organization, creating remuneration strategy for services in the primary care in 2001.25 In a comparative study between the APS coordination in the RAS between the cities of Lisbon, Portugal, and Rio de Janeiro, Brazil, evidently that Portuguese RAS, for having more time in the deployment, has a more extensive APS and with a better performance in the network coordination, unlikely Rio de Janeiro, which still has a selective APS with difficulties in management. 26

Despite this lack of primary health care integration with other levels of care, our study reported efforts in different health services (training for patients referral to specialized centers). Marchildon 27 identified the integration of primary care in Canada as the main obstacle in relation to physicians and regionalized structures. Aerde 28 stated that the absence of medical professionals and citizens in this process were two important factors of badly succeeded regionalization in Canada.

This present study identified the increase of investments for the healthcare network in NorthBarretos and South-Barretos regions, but also encountered limitations to verify if the regionalization was possible to reduce costs in the health system. However, International authors reported the impact on the economy scale by reducing the duplication of the health actions, improving the efficiency and, consequently, reduce costs with the regionalization.23,29 In Italy, the balance of the health budget also was strengthened by the regionalization. 13

The limitations of this study are related to the statistical data presentation in various scales, sometimes, in absolute numbers or in the average scores from the Likert scale by limiting the data cross-checking. The analysis on the CIR reports until the month of the interviewees, could have been hindered due to the lack of monitoring the final decisions on some discussed guidelines that did not have medical referrals until the present study.

\section{Conclusions}

This study allowed us to conclude that regionalization in the North-Barretos and SouthBarretos regions contributed more to the organizational aspect of services and health actions. In addition, there was a greater ownership on public health necessity with the RAS formation. The greatest difficulties identified among all the data sources in this study were in the health planning and management due to the lack of qualified human resources in the sector. The regionalization contributed a little for the improvement of the public-private correlation, human and financial resources. Despite the increase in financing funds for health, it was verified that the costs are a burden at the City Treasury without achieving the correct balance between the Federal and State spheres.

The regionalization policy in these regions of the study showed no contributions to a primary health care regional basis organization. International evidence demonstrated the difficulty to apply this health policy in primary care, and the Brazilian studies are confirming this same complexity. In addition, it was evident that the health region is not 
an area for a complete integrity care yet, making managers seek new articulations to guarantee care for the patients.

We also concluded that the CIR meetings in the North-Barretos and South-Barretos regions were more deliberative with little space for discussion. Thus, these intergovernmental forums have not fulfilled the role of being a collaborative space for negotiations on health issues in these regions in São Paulo State.

\section{References}

1. Arretche M. Trajetórias da Desigualdade: Como o Brasil Mudou Nos Últimos 50 Anos. Editora Unesp; 2015.

2. Albuquerque MV, Viana ALd'Ávila, Lima LD, Ferreira MP, Fusaro ER, Iozzi FL. Desigualdades regionais na saúde: mudanças observadas no Brasil de 2000 a 2016. Ciênc Saúde Coletiva. 2017;22(4):1055-64.

3. Ribeiro PT, Tanaka OY, Denis J-L. Governança regional no Sistema Único de Saúde: um ensaio conceitual. Ciênc Saúde Coletiva. 2017;22(4):1075-84.

4. Carvalho ALB, Jesus WLA, Senra IMVB. Regionalização no SUS: processo de implementação, desafios e perspectivas na visão crítica de gestores do sistema. Ciênc Saúde Coletiva.2017;22(4):1155-64.

5. Brasil. Presidência da República. 1988. Constituição da República Federativa do Brasil. Brasília: Casa Civil. Subchefia para Assuntos Jurídicos.

6. Albuquerque MV, Viana ALD. Perspectivas de região e redes na política de saúde brasileira. Saúde em Debate. 2015; 39 (n.especial): 28-38.

7. Santos AM, Giovanella L. Regional governance: strategies and disputes in health region management. Rev Saúde Pública. 2014;48(4): 622-31.

8. Lewis S, Kouri D. Regionalization: making sense of the Canadian experience. Health care Papers. 2004;5(1): 12-31.

9. Guerra DM. Descentralização e Regionalização da Assistência à Saúde no Estado de São Paulo: Uma Análise do Índice de Dependência. [tese]. São Paulo: Faculdade de Saúde Pública da Universidade de São Paulo; 2015.

10. Viana ALD. Descentralização e política de saúde: origens, contexto e alcance da descentralização. 2 ed. São Paulo: Hucitec; 2014.

11. Paschoalotto MAC. A regionalização do SUS: proposta de desempenho dos Departamentos Regionais de Saúde do Estado de São Paulo. [tese]. São Paulo: Faculdade de Economia, Administração e Contabilidade de Ribeirão Preto, Universidade de São Paulo; 2016.

12. Barata LRB, Tanaka OY, Mendes JD. Por um processo de descentralização que consolide os princípios do Sistema Único de Saúde. Epidemiol Serv Saúde. 2014; 13 (1): 1524.

13. São Paulo. Secretaria Estadual de Saúde. Diário Oficial do Estado. Decreto ${ }^{\circ} 51.433$, de 28 de dezembro de 2006. Cria unidade na Coordenadoria de Regiões de Saúde, da Secretaria da Saúde, altera a denominação e dispõe sobre a
We emphasize that the regionalization process in the North-Barretos and South-Barretos regions is still incipient and the service organization as a network is still in the implementation process. The training of health professionals in being able to work in a regional scope can assist and contribute to the development of innovations that support deeply the attributes of regionalization, as coordination and the integration of actions and services.

reorganização das Direções Regionais de Saúde. São Paulo, 2006.

14. Brasil. Ministério da Saúde. Portaria GM 4.279 de 30 de dezembro de 2010. Estabelece as diretrizes para a organização da rede de atenção do SUS. Brasília; 2010.

15. Mendes EV. As redes de atenção à saúde. Brasília: Organização Pan-Americana da Saúde, 2011.

16. Viana ALA, Lima LD, organizadoras. Regionalização e relações federativas na política de saúde do Brasil. Rio de Janeiro: Contra Capa; 2011.

17. Creswell JW, Clark VLP. Designing and conducting mixed methods research. 2 ed. London: Sage, 2011.

18. Região e Redes: o caminho da universalização da saúde no Brasil. Resumo executivo. Disponível em: http://www.resbr.net.br/a-pesquisa/resumoexecutivo/\#.WZL571GGM2w

19. Viana ALD, Bousquat A, Pereira APCM, Uchimura LYT, Albuquerque MV, Mota PHS, Demarzo MMP, Ferreira MP. Tipologia das regiões de saúde: condicionantes estruturais para a regionalização no Brasil. Saúde Soc. 2015; 24 (2): 413-22.

20. Organização Pan-Americana da Saúde. Redes e regionalização em saúde no Brasil e na Itália: Lições aprendidas e contribuições para o debate. Vol. 4, NAVEGADORSUS Série Técnica Redes Integradas a Atenção à Saúde;2011.

21. Vargas I, Mogollon-Perez AS, Unger J-P, Da-Silva MRF, De Paepe P, Vazquez M-L. Regional-based Integrated Healthcare Network policy in Brazil: from formulation to practice. Health Policy Plan.2015; 30(6):705-17.

22. Wickremasinghe D, Hashmi IE, Schellenberg J, Avan BI. District decision-making for health in low-income settings: a systematic literature review. Health Policy Plan. 2016: 31(2): ii12-ii24.

23. Bergevin Y, Habib B, Elicksen K, Samis S, Rochon J, Adaimé C, Boucher G, Denis JL, Roy D. Towards the Triple Aim of Better Health, Better Care and Better Value for Canadians: transforming regions into high performing. Canadian Foundation for Health Improvement. 2016.

24. Vrangback K. Regionalization from Denmark. Healthc Papers.2016;16(1): 21-6.

25. Tenbensel T. Health System Regionalization - The New Zealand Experience. Healthc Papers.2016;16(1): 27-33.

26. Lapão LV, Arcêncio RA, Popolin MP, Rodrigues LBB. Atenção Primária à Saúde na coordenação das Redes de 
Atenção à Saúde no Rio de Janeiro, Brasil, e na região de Lisboa, Portugal. Ciênc Saúde Coletiva. 2017;22(3):71324.

27. Marchildon GP. Where we are going from Here? Healthc Papers. 2016;16(1): 75-9.

28. Aerde J Van. Has regionalization of the Canadian health system contributed to better health? Can J Physician Leadersh. 2016;2(3):65-70.
29. Born K, Sullivan T,Bear R. Restructuring Alberta's health system. [artigo em formato eletrônico]. 2013. [acesso em $12 \operatorname{dez} 2016]$ Disponível em: http://healthydebate.ca/2013/10/topic/politics-of-healthcare/restructuring-alberta-health

Received on May 29, 2017

Final version presented on September 12, 2017

Approved on September 20, 2017 